\title{
Aspirations in Transnational Religious Networks
}

On a cool August night in 2003, I walked with Raouf through his hometown in northern Mauritius. We were going to the house of his relatives, the parents of Naseem, whose wedding was going to be held the next day. That night before the wedding, a mahfil-e mawlud was to take place at Naseem's parents' house. Arriving at the house before the performance, we met Anwar, who was to be one of two main reciters of na't this evening. Anwar was a student in a dar-al 'ulum recently constructed in a small town in the east of the island, and he was a spiritual follower (murid) of Maulana Shah Ahmad Nurani, who until his death in 2003 was also a prominent figure in Pakistani politics. A great emphasis on saint veneration and practices of intercession formed part of Anwar's education at the seminary. It also constituted an important part of the background for the na't recitation that would take place that evening. Islamic institutions in Mauritius tend to maintain close links with centers of religious authority in South Asia, and this was also the case with the newly established dar-al 'ulum in the east of the island that Anwar attended.

The dar-al 'ulum in Mumbai that supervised the new academy had recently sent what is believed to be a hair of the Prophet and a hair of the famous twelfth-century saint-teacher 'Abd al-Qadir Jilani, to be kept as sacred objects in the new institution. In 2002, a maulana who headed a Barelwi institution in Mumbai brought the sacred hairs to Mauritius. Both hairs reportedly continue to grow. Before the performance, Anwar showed me a photograph of the still only half-finished daral 'ulum, in which what appear to be rays of light emanate from the part of the building that houses the blessed hairs (bal mubarak), a phenomenon that Anwar and several others present attributed to a miracle. Several of those attending the 
mahfil-e mawlud surrounded Anwar as he held the photograph, discussing precisely which part of the then unimpressive and unfinished building the light was emanating from. Six years later I heard from an Urdu teacher, who is also a locally known na't khwan, that the maulana had in the meantime given ghuzl (full ritual washing) to the hairs when he last came to Mauritius. Reportedly, the water that had come in contact with the hair had cured a cancer patient who subsequently drank it.

Not only in Mauritius, but also in the wider South Asian world and its diasporas, the Ahl-e Sunnat wa Jamaat tradition is known for propagating devotional practices such as the recitation of devotional genres in honor of the Prophet and other Islamic authorities. It also encourages the veneration of prominent Sufi saints. The new dar-al 'ulum Anwar attended is also under its control. For students of Sufism, not only the telling of miracles but also the reference to light in the vignette above is hardly surprising, given the influence of the Sufi conception of the nur-e muhammadi, the continuing presence of the Prophet manifest as pure light (Schimmel 1975: 224). The opportunity to perceive it is often a highly desired goal for those engaged in Sufi practices in devotion, an ultimate spiritual reward that suddenly suspends the multilayered steps of spiritual progress and processes of mediation separating the devotee from the divine through the relative immediacy of light.

Mauritian Muslims affiliated with the Ahl-e Sunnat maintain dense transnational ties to religious organizations and centers linked to the same tradition in other countries of the Indian Ocean region, most importantly, India, Pakistan, and South Africa. To give only a few examples, in Pakistan, Maulana Shah Muhammad Anas Nurani Siddiqui Qadri Madani, the grandson of the Barelwi 'alim and missionary Abdul 'Alim Siddiqi, a follower of Ahmad Riza Khan Barelwi and the founder of the Ahl-e Sunnat tradition in Mauritius, headed the Jama'at-e Ulama-e Pakistan, the political party representing the Barelwi 'ulama and affiliated institutions until 2008. Like his father, the late Maulana Shah Ahmad Nurani, and his grandfather, he regularly visits Mauritius, where he is hosted by the Jummah Mosque in the capital, Port Louis. He is also the president of the World Islamic Mission, an international network originally founded by Shah Ahmad Nurani in 1972 and closely connected to the Jamaat-e Ulama-e Pakistan. The World Islamic Mission plays an important role in recommending candidates for the position of imam of the Jummah Mosque in Port Louis, whom Mauritian Muslims following the Ahl-e Sunnat also recognize as the mufti of their country. The Jummah Mosque is controlled by the Kutchi Memon Society of Mauritius, and ever since independence in 1968 the Mauritian government has treated the mosque as the official representative of the Muslim community of the country. Since the turn of the century the Da'wat-e Islami, a transnational Islamic missionary movement that propagates the Barelwi tradition, and which is consciously modeled on the 


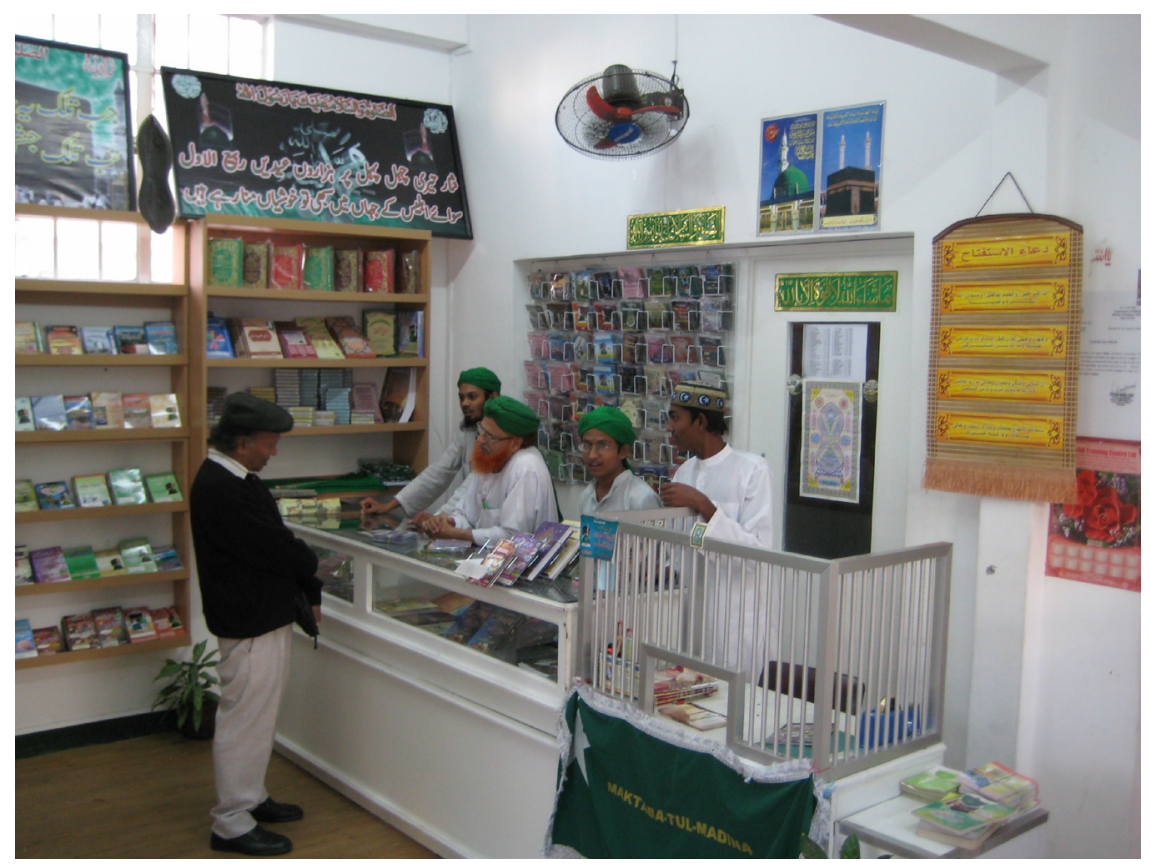

FIgURE 3. Center of the Da'wat-e Islami in Port Louis, Mauritius. Photograph by the author.

Tabliqi Jama'at (Gugler 2011), has also come to Mauritius. In 2009 its members held weekly meetings in five locations and went on weekly missionary tours throughout the island. The movement is locally headed by two Pakistani brothers married to Mauritian women and is closely linked to its center in Karachi. The recent security-related restrictions on foreign students who wish to enroll in daral 'ulum in India and Pakistan have made the religious ties to Barelwi institutions in South Africa, particularly in Durban, Port Elizabeth, and Pretoria, much more important for Mauritians, and these three cities are now among the main destinations for those seeking an Islamic education abroad.

As can be expected, the Ahl-e Sunnat-related ties between Mauritius and India are manifold. For a long time, savvy use of modern media had not been seen as typical of Barelwis and their leaders, since the movement, founded by Ahmad Riza Khan Barelwi, is often regarded as the exponent of Sufi-linked popular Islam associated with the rural and small-town milieus of northern India. But this has changed. In Mumbai, the Raza Academy, a Barelwi publishing house and activist platform founded in 1978, maintains a web portal that includes directories of associated institutions and ulema. However, it is, above all, the sheer mass of "small" media, especially audio and video CDs of devotional poetry performances and religious speeches and sermons, that make up the Barelwi media universe in Mumbai. 
The web portal also provides links to other locations where the same media circulate. When I met the founder and head of the Raza Academy in Mumbai in 2009, he told me that he was attending the arba in (commemorative gathering on the fortieth day after a person's death) of Sarfaraz Naimi, a Barelwi 'alim in Lahore who had been assassinated by a Taliban-linked suicide bomber in his seminary the previous month. But another purpose of his trip to Pakistan the following day was to collect the latest audio and video CDs of na't, manqabat (Sufi poetry in praise of saints), and sermons from there so that upon his return he could give them to local entrepreneurs to copy and redistribute in India.

In Mauritius local media companies such as Etoile Brilliant Sound specialize in quickly producing and distributing audio recordings of recitals of nat and manqabat by Mauritian performers. Even when audio CDs of nat performances are locally recorded and produced in Mauritius, there is often an effort to link such recordings to a source in South Asia deemed to be authentic. For example, an Urdu teacher in a village in northeast Mauritius who is known as an accomplished na't khwan, having won a prize at one of the yearly televised na't competitions by the state-run Mauritius Broadcasting Cooperation, has produced a CD with accompanying booklet under the sponsorship of the dar-al 'ulum linked to a maulana in Mumbai. Even though this $\mathrm{CD}$ is his own production, he has taken care to stress that the na't performed were all composed by Ahmad Riza Khan Barelwi and taken from his collection of poetry titled Hada 'iq-i bakhshish (Khan Barelwi n.d.). In matters of style (taraz) and mode of musical recitation (tarannum; Qureshi 1969), he claims Fasihuddin Soharwardi as his example to emulate, and to me he described the moment when the visiting Soharwardi embraced him after having listened to his na't recital at the Mauritius Broadcasting Cooperation competition a few years earlier as the greatest honor he ever received in his life.

Both in Mauritius and Mumbai, I found that religious personalities and others involved in the running of mosques or dar-al 'ulum, such as the mutawalli (president) of the Jummah Mosque of Port Louis, were eager to establish transnational links, to exchange visits by imams and religious students, and to share media such as books, CDs, and DVDs. Mauritian institutions invite and host religious authorities and other specialists and cover their costs of travel, while those invited give sermons, recite the Quran, provide instruction to students, bring books and electronic media, and, sometimes, as I described above, even bring sacred objects with them. Until recently, Mauritian students would also be sent to dar-al 'ulum in India. But the reasons why Ahl-e Sunnat-affiliated Muslims sought to take part in the transnational network between Mauritius and Mumbai differed.

In Mauritius, some hoped that such links would enhance the credibility and status of the institutions they were running and to which their livelihoods were also connected. For example, the then-half-finished dar-al 'ulum that received the maulana from Mumbai who, as mentioned earlier, had donated the sacred hairs to the institution on his visits to Mauritius, was the project of the local imam and one 
of his local allies who unsuccessfully ran for the office of president in the mosque council. The imam's partner and cosponsor also owned a hardware and building materials store and a small construction business, which had carried out the work realized so far. But at the time of my research, substantial work still needed to be done to complete the construction of the dar-al 'ulum, and for this the imam and his partner depended on local donations by those who were convinced of the enterprise's worthiness and its religious credentials. Despite the presence of the bal mubarak, with their miraculous emanation of light, and the visits by the maulana from Mumbai, some doubted the legitimacy of this undertaking and its associated fund-raising. Similarly, in another town in the east of Mauritius a few kilometers away, another religious specialist, whom I call Imam Parvez, had a plan to build and extend a dar-al 'ulum. He established a similar connection to Mumbai, in this case to a well-known dar-al 'ulum, an affiliation that at the time was also proudly displayed on his website set up by his son. A few years earlier, he had traveled to Mumbai with his son, where he met the president of the dar-al 'ulum, who is also a Sufi sheikh. The ambition of this imam, too, is to raise funds locally for the purchase of a new, bigger building. Years before this, he had failed to become an Urdu teacher, and serving as imam and head of the dar-al 'ulum is now his main occupation. In 2009, his efforts to raise funds suffered a serious setback when money he had locally collected to be used for qurbani (ritual sacrifice of an animal on the occasion of Eid al-Adha) in India turned out to be unaccounted for. Needless to say, many local Muslims suspected motives of personal gain behind the fundraising for the extension of the dar-al 'ulum that this imam is seeking to legitimize with his ties to a Barelwi institution in Mumbai.

Another theme connected with participation in transnational Ahl-e Sunnat networks is what many of my interlocutors who were followers of the Ahl-e Sunnat called the "struggle against the Wahhabis." Followers of the Ahl-e Sunnat frequently use Wahhabi as a derogatory blanket term for their religious opponents, even those not actually affiliated with traditions of Salafism and Wahhabism, such as the Deobandis, including the Tabliqi Jama'at, who, like the Ahl-e Sunnat, follow the Hanafi school of law. When I met the head of the Raza Academy while visiting his office in Mumbai in 2009, he opened the conversation by asking me what I thought the reasons were for Wahhabis making so much headway everywhere. In fact, throughout India and Pakistan and also in Mauritius, the Barelwi ulema are steadily losing followers to the missionizing efforts of the Tabliqi Jama'at and the Salafis (Alam 2009, Sikand 2007).

The transnational dimensions of this sectarian rivalry and threat to the Barelwi constituency and Barelwi institutions are obvious. Without exception, all the Mauritian imams and ulema affiliated with the Sunnat Jama'at (Ahl-e Sunnat) that I have ever met have said they find it necessary to also fight this threat transnationally with the help of media. For example, one imam in northern Mauritius who is known for his video sermons in Mauritian Creole in support of the Sunnat Jamaat put it this 


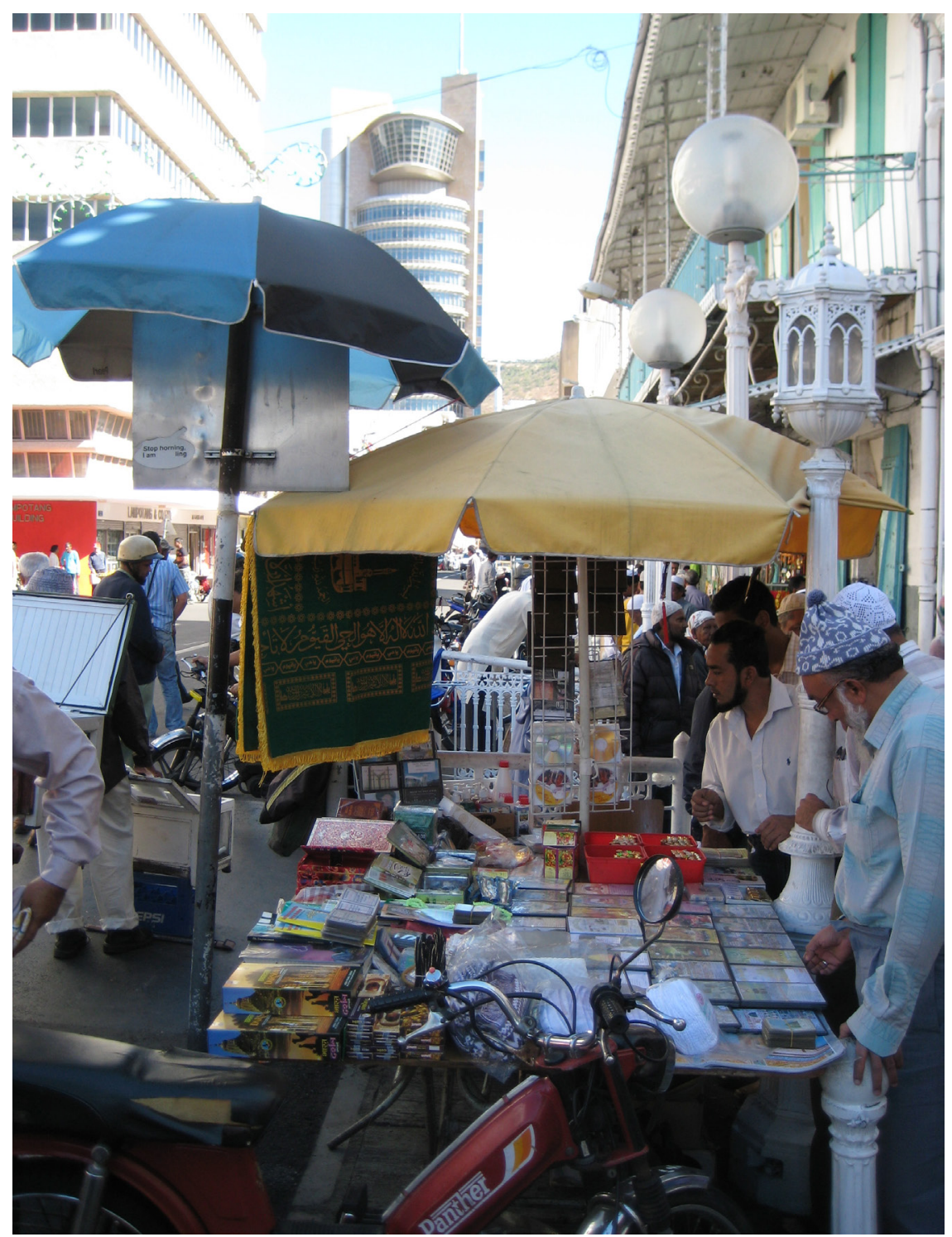

FIGURE 4. Stall selling CDs and DVDs in front of the Jummah Mosque, Port Louis, Mauritius. Photograph by the author.

way: "The Wahhabi are sincere, but they have wrong ideas. Their arguments are not good, but their salesmanship is [Zot ban largiman pa bon, me so salesmanship li bon]. In contrast, the Sunnat Jama'at's arguments are good, but their salesmanship is not. Their way of presenting is not good [Zot fason presante pa bon]." 
In Mauritius, sectarian rivalry was even a key impetus in the formation of Ahl-e Sunnat networks between Mauritius and India in the very beginning. In fact, when the Kutchi Memon leadership invited Abdul 'Alim Siddiqi to visit Mauritius for the first time in 1928, one reason for bringing Siddiqi to preach and missionize on the island was to counter the Ahmadis, who at the time were at the peak of their influence among Mauritian Muslims (Donath 2013: 181-182, Jahangeer-Chojoo 1997: 211-212).

In Mumbai's Bhendi Bazar neighborhood, a maulana who heads a dar-al 'ulum and is imam of the adjacent Sunni mosque stands for a rather different kind of transnational Ahl-e Sunnat network with Mauritius, which very much resembles an extension of established Sufi murshid-murid (spiritual master-disciple) relationships in the Firdausi and Qadriyya Sufi orders (silsila). Since the nineteenth century, Bombay has been an important hub in the formation of a transoceanic shrine-based religious economy involving Sufi ties (Green 2011). The maulana belongs to a family connected to the well-known Firdausi (a collateral line to the Suhrawardiyya order) shrines of Bihar Sharif and Maner in Bihar. The maulana's father, who had migrated to Bombay from Bihar-incidentally an area from which large numbers of people migrated as indentured laborers to Mauritius in the nineteenth century-established the mosque in the Bhendi Bazar neighborhood in 1929. When I inquired at the mosque about a meeting with him, explaining that I had recently come from Mauritius, where I had often heard his name mentioned in the previous few years, the maulana displayed the impressive demeanor of a Sufi sheikh. I could see him being revered by his followers who were bowing before him, following him deferentially and kissing his hand, while gently stroking their faces and hair with their hands that just had received the touch of the sheikh. When he received me in his office after the maghrib prayers on a rainy evening in July 2009, the atmosphere immediately resembled that of a small darbar (courtly setting). The maulana sat on an elevated thronelike pedestal in front of a low desk with a calendar, books, a landline phone, and two fancy cell phones on it. At the other end of the small, air-conditioned room, two young men stood stiffly next to the door under a large picture of the shrine of Ahmad Riza Khan in Bareilly in the North Indian state of Uttar Pradesh, with its characteristic black-and-white dome. In the middle part of the room, the maulana's sons and the teachers and senior aides in the dar-al 'ulum sat on the floor, while supplicants could be seen quickly entering and leaving the room, kneeling before the sheikh in the hope of receiving a hearing of their requests. Receiving the honorable treatment extended to a foreign guest, I was assigned a place on the floor with a comfortable cushion right in front of the sheikh's pedestal to begin my audience. I was, after all, placed in the role of a seeker of truth, who had come from far away to learn about the Ahl-e Sunnat wa Jama'at. Confirming most of what my Mauritian interlocutors had told me about him, he recounted how he had come to Mauritius for the first time in 1988, at the invitation of a Mauritian businessman from a suburb of Port Louis. This man, 
while on a business visit to Bombay, came to offer Jummah prayers at his mosque and, subsequently, became his murid. The businessman's family has been hosting the maulana in their home in a suburb of Port Louis on his almost yearly visits to Mauritius ever since. While the maulana is also invited by the Jummah Mosque and the Sunni Rizvi Society of Port Louis during his stays, his network consists of an independently established and growing circle of murid, who revere him as a Sufi sheikh. An enlarged and framed photograph of the light emanating from the two bal mubarak the maulana had brought to the half-finished dar-al 'ulum in eastern Mauritius could be seen on the wall of the sheikh's office and reception room above a picture of the shrine of 'Abd al-Qadir Jilani in Baghdad. It was the same photograph that Anwar had shown me in Mauritius six years earlier. The personal encounters with the traveling Sufi sheikh, his visual appearance, noble lineage, and his embodiment of piety, as well as his mastery over sacred objects, ultimately constitute this Ahl-e Sunnat network between Mumbai and Mauritius. The bodily presence of the sheik itself is the medium of the divine, and the promise of miraculously apprehending the divinely inspired light its aspiration.

Among my interlocutors in Mauritius, I often heard doubts about whether these transnational ties and exchanges were "really" in the service of propagating the Ahl-e Sunnat, and not just undertakings for personal, and even monetary, gain. In Mauritius, not only the suspicions and actual accusations of embezzlement in fund-raising activities by Mauritian imams connected to the Ahl-e Sunnat network, but also the visible economic side activities of visiting Indian maulanas, mostly in the textile trade, led some to the conclusion that those who use such transnational networks ultimately do so for personal gain and economic profit. As Asif, an accountant in his early thirties from a town in northern Mauritius, put it, "I have often observed these maulanas coming and going, and have listened to imams who have great ambitions to start a new dar-al 'ulum here and there. But in the end I think there is always a personal interest. I don't believe it is just to spread the message of Islam." That is, for some of my Mauritian Muslim interlocutors, the setting up and perpetuation of a transnational Ahl-e Sunnat network is to an important extent firmly rooted in the local ambitions of religious entrepreneurs. Accordingly, aspiring to the cosmopolitan credentials derived from involvement and visibility in such a network can be traced back to local politics in a Mauritian town or a Mumbai neighborhood.

But the opposition some of my interlocutors drew between "true" religious aspirations on one hand, and personal and political aspirations on the other hand, requires reconsideration. Especially on the Mauritian side of the network, the desire for more "direct" relationships to centers of religious authority located elsewhere, and political and economic aspirations in a local context, cannot be neatly separated. Claims of a more immediate connection to desired centers of political and religious power, or to desired moral values and goods, often go hand in hand with claims to power in other political and economic domains. Thus, the link 
between religious aspirations in a transnational network and local political and economic ambitions does not easily fit an instrumentalist account. These elements are often part of the same process, so that aspirations to establish more intensive links to religious authorities and the places associated with them cannot simply be reduced to desires for socioeconomic mobility.

\section{RELIGION AND GLOBALIZATION}

Asif's observations and those of others among my Mauritian Muslim interlocutors on the possible motives of actors involved in transnational Islamic networks between Mauritius and South Asia raise the question of the relationship between religion and globalization, which is a focus of growing interdisciplinary interest. For quite some time it has been obvious that theories of modernization and secularization do not account for the growing visibility of religious mobilization in the contemporary globalizing world. In many parts of the world the spread of modern ways of life has also been accompanied by the foregrounding of religious identities, as well as by heightened activism in the field of religious reform, conversion, and the emergence of piety movements in a wide range of religious traditions. Nevertheless, until recently theories of globalization have said relatively little about religion. Among those approaches that do focus on the role of religious practices and traditions, the religious manifestations of globalization have often been treated as an epiphenomenon of what many analysts of globalization often consider its core dimension-the spread of neoliberal capitalism. For example, heightened religious activism is often interpreted as a symptom of unequal development, as a stress symptom among marginal and deprived people who struggle to make sense of the new complexity and the upheavals that the introduction of global capital brings about. This interpretation has been especially popular in the analysis of the spread of religious "fundamentalism" under conditions of globalization, where analysts have taken the former as "a defensive reaction against the fear of a violent uprooting of traditional ways of life" (Habermas 2003: 32; see also Castells 2004).

The study of Islam and globalization is a case in point. In a range of studies, developments such as the rise of Islamist movements, the growing presence of the various piety movements in the Muslim world, and, more generally, the spread of orthodox and standardized forms of Islam are portrayed as ultimately traceable not to the dynamics of religious traditions themselves but to forces outside religion. For example, Olivier Roy has argued that the rise of contemporary Islamism and literalist movements such as Salafism is tightly connected to the cultural disruptions and dislocations that characterize migration in a globalizing world, making uprooted people susceptible to simplified and "fundamentalist" forms of Islam that are not bound to particular cultural backgrounds (Roy 2004).

More recently, anthropological studies of religion under globalization have sought to correct the image of religion as a relatively marginal and epiphenomenal 
dimension of globalization that continues to guide investigations of the links between religion and globalization. Thomas Csordas, for example, has posited religion's centrality in globalization processes at large. Stressing the interdependent relationships between religious and other dimensions of globalization, he points out that neoliberal discourses and ideologies of globalization have strong religious overtones (Csordas 2009). This perspective is somewhat different from what Jean and John Comaroff have described as the interdependency of religious mobilization and what they call "millennial capitalism." According to them, alongside a range of other social phenomena, recent religious expansions such as Pentecostalism are ultimately "concrete, historically specific outworkings of millennial capitalism and the culture of neoliberalism" (Comaroff and Comaroff 2000: 334; see also 310-315). Putting more stress on the significance of religious traditions in assessing the relationship between religion and capitalism as two key dimensions of globalization, Joel Robbins argues that religious ontologies and local understandings of global capital are often tightly interlinked. Theorizing about religions that emerged from an "axial age" — such as Christianity-and which posit a stark opposition between this world and a religious otherworld, Robbins points out that such religious cosmologies not only make such religions more transposable between cultural contexts but also have a profound impact on how people locate themselves within relationships of center and periphery that are central to the workings of globalization. Further, he suggests that religious traditions that resonate most powerfully with the experiences of marginality that are foundational to the experiences of globalization for many are also most likely to thrive in the contemporary world (Robbins 2009). My analysis of religious mobilizations among Muslims in Mauritius speaks to these approaches that stress the interdependency of religious and other dimensions of globalization.

Mauritius is an extreme example of a society that at no point in its history found itself outside processes of globalization. Uninhabited in precolonial times, the island was taken over by a succession of Dutch, French, and finally British colonizers, who turned it into a maritime outpost, a trading entrepôt, and eventually a plantation colony. Its entire population traces its origins to other parts of the world, owing to the migration of French and other European settlers and colonial administrators, and Indian, Chinese, and European trader families, as well as the ancestors of the vast majority of Mauritians, who were brought to the island as slaves or indentured laborers. Since the beginnings of contemporary neoliberal globalization and the setting up of "export processing zones" in the late 1970s, economic activity in Mauritius changed from dependency on a vulnerable sugar monocrop, which left most of the population poor, to rather successful and diversified arrangements. The latter above all rest on textile manufacturing and tourism and, more recently, also include information technology and finance services. With further intensified integration into global economic flows since the early 1980s, the majority of Mauritians have experienced vast improvements in their standard 
of living, in addition to expanded public infrastructure in the fields of education, health, and transport, and in the provisions of a rudimentary welfare state. Hailed in the 1990 os by the World Bank as an "economic miracle," Mauritius has been one of the success stories of economic globalization in the non-Western world.

\section{RELIGIOUS MOBILIZATIONS IN MAURITIUS}

Since independence from Britain in 1968, the Mauritian government and state institutions have been dominated by middle-class Hindus, particularly those of North Indian background. Under their leadership, state institutions in this former plantation society have embarked on a politics of cultural citizenship that stresses the origins of Mauritians in other parts of the world. The promotion of diasporic "ancestral cultures" with colonial genealogies that, in turn, largely consist of religious traditions is the most salient aspect of this policy of nation building. ${ }^{2}$ As mentioned before, Islamic traditions play the role of an official ancestral culture for Mauritian Muslims, who share with Hindus an Indian origin. Such recognized ancestral cultures enjoy not only the support of transnational networks but also the encouragement of Mauritian state institutions. The latter are concerned about managing and regulating the relations between the different religious groups in Mauritius. Violence between Hindus and (Christian) Creoles in 1999 heightened concerns about the competition and political struggle between members of different ethno-religious groups that took the form of destructive "communalism."

In Mauritius, Gujarati trader families, who settled on the island as free immigrants with often substantial amounts of capital, have traditionally played the role of Islamic institution-builders. Originating in western India, these traders used the colonial connections established in the context of British imperial expansion in the nineteenth century to settle in and move between East and South Africa, Madagascar and the Mascarenes, and the Persian Gulf and Southeast Asia (Markovits 1999, Kalla 1987). They have largely been responsible for the spread of reformist and more standardized forms of Islam in Mauritius. ${ }^{3}$

Nissar Ramtoola is the mutawalli (president) of the Jummah Mosque of the capital Port Louis, which the government recognizes as the chief mosque of the country. He belongs to the Kutchi Memon community, who built the mosque in the nineteenth century and have controlled it ever since. Being fluent in English, French, Mauritian Creole, Urdu, and Gujarati, he has extended family connections throughout India and South Africa, as well as the United Kingdom, and is part of a prominent trader family that owns an important business agglomerate in Mauritius. These links are paralleled by the religious networks of the Ahl-e Sunnat wa Jama'at, or Barelwi, tradition that extend between these places. For example, a Barelwi Sheikh from Durban is the spiritual guide of Nissar Ramtoola's children, and in his function as president of the mosque he regularly hosts imams, 
accomplished performers of devotional poetry, and other religious authorities from South Asia. He has also set up links between the mosque and a dar-al 'ulum in Pretoria that translates Barelwi writings from Urdu into English, and with an Islamic college in Coventry that trains ulama. Highlighting the claim that the mosque is the supreme Islamic authority in the country, Nissar Ramtoola played down the sectarian struggles among Mauritian Muslims and their transnational ramifications. In conversation with me, he stressed instead that "we are the chief mosque in the country, and we are open to all regardless of their affiliations. We represent the chief authority in many practical questions, such as halal certification and the end and beginning of Ramadan; we are open to all in search of guidance, to those who have questions about how to live as a good Muslim in the modern world. Therefore, my goal is to make the Jummah Mosque more interactive and to be more internationally active."

He also compared the mosque and its work to a fine car that is in need of a "good driver," by which he meant Western-style businesslike forms of advertisement, networking, and organization. Nissar Ramtoola illustrates a relationship between religion and globalization in which there are seamless connections between international businesses and a transnational network of a standardized form of Islam. ${ }^{4}$ These connections have in turn led to the emergence of a cosmopolitan habitus that links this transnational religious network not only with the ability to travel to and be in regular interaction with a broad range of places in the world but also with the ability to conduct life in a way that could potentially be followed almost anywhere. The cosmopolitan credentials of the president of the chief mosque in Mauritius also lend authority to his leadership over what he insists is the most important mosque for all Muslims in Mauritius, despite its actual sectarian affiliation. As the example suggests, the cosmopolitan often contains claims of authority and superiority over others, illustrating its context-bound and contested nature (cf. Hawkins 2010).

It is precisely this combination of superior education and wealth, a taken-forgranted cosmopolitan familiarity with other parts of the world, and the credentials of being part of an authoritative and transnational Islamic network, that Muslims whose ancestors were indentured laborers often jealously admire and seek to emulate. The Fokeerbux family in eastern Mauritius, for example, has successfully done so. Having built a small retail and real estate empire in the small towns of northern and eastern Mauritius, where they own several shopping arcades and household and electronics stores, they now count as the wealthiest non-Franco-Mauritians in their area and engage in regular travel for business or religious reasons. In their home village in the northeast, the founder of the family business has built a large, ostentatious mosque ornamented with elaborately decorated imported tiles and a massive dome that is unusual for Mauritius, especially in this quiet village where there already was a mosque of the same sectarian affiliation catering to the Muslim inhabitants of the village. 
But many Muslims of formerly indentured family lines who struggle to get by also strive for education, money, and above all recognition by others through linking up with the transnational. As I described earlier, Imam Parvez is aiming, from a much less advantageous position, at the kind of respect and economic improvement that transnational links - to places where business is intertwined with religious networks - can provide. Coming from a small planter family, he now works as a largely self-trained imam with no dar-al 'ulum credentials. In a modest building, he started an Islamic academy by himself and is now trying to extend it. A few years ago he started to collect donations for an extension of this academy in the eastern town where he lives. As I described in the previous chapter, crucial to this effort are the links that he has established to a Barelwi dar-al 'ulum of Mumbai to strengthen his project. His son Nizam assists him in running the dar-al 'ulum and has now found a job as a boat operator in the tourism trade. Reminiscent of Nissar Ramtoola's characterizing of Indian Ocean-wide religious links through a rhetoric of business and advertising, the imam's son also expressed the intertwining of transnational religious and economic networks in a language of marketing. Stumbling over cardboard boxes in the crammed and modest office of the dar-al 'ulum, Nizam compared the combination of religious activities, travel to India, and fund-raising in a businesslike way: "We need to protect our community from the activities of the Salafis and Wahhabis. The main problem we have with them is that they do not respect the Prophet but treat him as an ordinary person, and then they criticize us when we show him the respect we are obliged to show to him, and [they] lead people astray. But it is not enough to just follow the Sunna of our Prophet; one also has to advertise what one does."

The donations have enabled the imam and his son to travel to India to visit Barelwi 'ulama and Sufi Sheikhs in order to obtain endorsements for their dar-al 'ulum project, a trip on which they also purchased textiles in India for resale in Mauritius. In the previous year, the dar-al 'ulum in Mumbai had sent a hafiz (a person who has memorized the Qur'an) to supervise the dar-al 'ulum's Ramadan program, seeking to boost its attractiveness. Here, too, striving for economic development and the intensification of global links has occurred alongside religious mobilization. But the same processes have also led to deep divisions among Mauritian Muslims who have aligned themselves with different networks of transnational orthodoxy.

However, this trend toward standardization and transnational orthodoxies has a history that predates the latest wave of globalization, beginning with the unfolding of the Mauritian "economic miracle" in the late 1970s and early 1980s. Ultimately, it started with the breakup of the "Indian," or Indo-Mauritian, community that originated with indentured ancestors. Preceding the rise of sectarian divisions among Muslims as a consequence of competing piety movements, the period immediately following the Second World War already saw the beginnings of a profound split between Mauritian Hindus and Muslims. The great majority of Hindus 
and Muslims came to Mauritius as indentured laborers in the nineteenth century, largely originating from what are now the Indian states of Bihar and eastern Uttar Pradesh. Many Hindus and Muslims have shared origins in northern India and can trace their ancestry back to the same districts or even villages. Their immigrating ancestors had been speakers of the regional language Bhojpuri, which remains in use in a particularly Mauritian variety across the religious divide (Eisenlohr 2006a). Hindus and Muslims shared the often harsh lot of indentured workers in the sugarcane fields, lived together in the long, very basic barracks provided by the plantation owners, and later lived amiably side by side as small sugarcane planters in the emerging Indian-dominated villages of rural Mauritius. For a long time the memory of having forefathers who had traveled in common on the same boat to Mauritius was kept alive in the villages as a form of ritual kinship (jahaji bhai) across religious lines. The religious divide was much less salient and also more permeable in the past, when religious and other ritual practices of immigrant Indians appear to have been as much influenced by the shared nineteenthcentury regional and rural background of most indentured immigrants from India as by their affiliation with two separate religious traditions. The reformist Hindu and Islamic movements that have shaped the contemporary religious and political landscape of South Asia and its diasporas were only beginning to emerge at the time when indentured migration to Mauritius and other overseas sugar colonies was already in full swing. The purist and more standardized versions of the traditions they were propagating had barely reached the rural districts from which most of the indentured migrants departed and had not influenced them to any significant extent. It was, for example, common for Muslims to participate in devotional gatherings where folk versions of the Ramayana were chanted, while on the other hand indentured laborers of all religious backgrounds took part in the "Ghoon" or "Tazia" procession on the tenth day of the month of Muharram to commemorate the martyrdom of the Prophet's grandson Husayn in the battle of Karbala. Even though widely regarded as a Shi' $i$ ritual, a broad range of Indo-Mauritians joined in the procession, which resembled an inclusive folk festival more than a Shi' $i$ event of commemorative mourning (Edun 1984, Jahangeer-Chojoo 1997: 278-281; see Williams 1990 and Korom 2002 for a comparable trajectory of this public ritual in the Caribbean). Starting at the turn of the twentieth century, "respectable" Muslims began to reject this exuberant and communally mixed festival owing to an increasing trend toward religious orthodoxy. Already in 1912 the Mauritian civil servant R. N. Gassita, himself a Muslim employed in the Education Department, noted that the relatively poor "créoles Lascars," Muslims of mixed Indian sailor and African background who had been present in Mauritius since the French colonial period (1715-1810), were the only ones left to celebrate the "Ghoon." "This festival that extends over ten days draws a large crowd to the eastern suburb of Port Louis. However, the majority of Muslims, considering it pagan[,] refrain from taking part in it. On the other hand, many non-Muslims attend" (Gassita 1912: 306). 
Another frequently observed example are Muslim wedding ceremonies and their attending festivities, which for more than a century have been subject to pressures of "Sunnification" (Benedict 1961: 142, Hollup 1996; see also Bal and Sinha-Kerkhoff 2007: 128, Jahangeer-Chojoo 1997), a process that already appears to have been under way in the early twentieth century. According to Gassita, whose observations were published in 1912, "After the marital blessings, the dancing-girls perform, but since recently this indecent luxury tends to disappear. This is a purely Hindu custom" (Gassita 1912: 312). However, the process of religious purification and standardization unfolded gradually, and shared ritual practices and modes of participation in rituals did not disappear overnight. For example, in Indo-Mauritian villages both Hindus and Muslims often left offerings such as cigarettes, camphor, or flowers at tree shrines dedicated to Dee Baba, a minor guardian deity. Despite long-standing trends toward orthodoxy, my older interlocutors, when remembering the decades preceding independence in 1968, described Indo-Mauritian villages as places of blurred religious affiliations and shared (even if hierarchically structured) participation in religious rituals. They recalled them as lifeworlds where neighborly solidarity and frequent social interaction across religious lines was considered the norm, and where occupation, dress, and other forms of consumption did not allow one to make easy distinctions between IndoMauritians of Hindu or Muslim backgrounds.

By the end of the Second World War, three interrelated developments were beginning to have a profound impact on this shared Indo-Mauritian world. First, Hindu and Muslim elites in Mauritius entered into political competition as radical changes in the colony's constitution allowed many Indo-Mauritians to vote for candidates in the legislative assembly for the first time, and as decolonization became increasingly imminent. The erstwhile leader of the Kutchi Memons, Abdul Razack Mohamed, set up the political party Comité d'action musulman, which was successful in attracting most of the Muslim votes in the late 1940s and the 1950s. Hindus, on the other hand rallied behind the Labor Party, which was gradually dominated by an emerging elite composed of Hindus descended from indentured ancestors who had returned from India and Britain with university degrees. The party was led by the Hindu politician Seewoosagur Ramgoolam, who, in 1968, would become the first prime minister of independent Mauritius. ${ }^{5}$

A second development that played a large role in the breakup of an "Indian" community in Mauritius was the steadily intensifying missionary and religious activist network between Mauritius and India. As already mentioned, beginning in the late 1920s Barelwi sheikhs and missionaries visited Mauritius and, for the first time, introduced a reformist and rather orthodox form of Islam among Mauritian Muslims. These Indian imams and sheikhs stayed in Mauritius at the invitation of the Kutchi Memon traders, who had developed a close relationship with the Barelwi tradition in India and beyond. Aided by the legitimacy bestowed by these 
Indian Islamic authorities, the Kutchi Memon leadership was active in mosque building and in normalizing and purifying religious practice among Mauritian Muslims. Among Hindus, missionaries of the reform movement Arya Samaj had begun to arrive in Mauritius in 1910, followed by proponents of the neoorthodox Sanatan Dharm movement in the 1920s. In the late 1940s, these networks were further sustained by the growing number of educated Hindus who went to study in India, and the long-standing trade networks of the Muslim Gujarati merchants with India and the rest of the Indian Ocean region. A third and closely related development was the Indian partition of 1947, whose impact was felt deeply in Mauritius, as the reactions of Indo-Mauritians to it were largely predetermined by the religious networks in which they already found themselves. Seen in relative terms, reformist Hindu and Islamic movements were, at the time of partition, already more influential among Mauritians of Indian background than in India itself. These connected trends were responsible for spreading more orthodox and purist ideas about and practices of Hinduism and Islam in Mauritius, and helped shrink the old spaces of Indo-Mauritian community and sociability that had developed through the shared experiences of indenture and political and economic marginalization in colonial Mauritius.

After independence from Britain in 1968, members of the Hindu elite quickly acquired dominance over the Mauritian government and state apparatus. They were faced with the task of postcolonial nation building in a former plantation colony, where deep communal and ethno-religious boundaries were integral not only to the old division of labor but also to the very self-understanding of a hierarchized "plural society" built around the sugar industry. Instead of adopting a strategy of suppressing and gradually erasing these boundaries through a politics of national homogenization-as, for example, attempted in the Creole nationalism adopted by postcolonial Caribbean states-Hindu elites embarked on a politics of cultural citizenship that emphasized the legitimacy of separate "ancestral cultures." These "ancestral cultures," in turn, center largely on religious traditions, such as Hinduism and Islam. Under this regime of citizenship and nation building, the visibly intensified engagement with Islamic traditions has not removed Mauritian Muslims from the national mainstream, despite their minority status; on the contrary, it has strengthened their claims for inclusion. Writing about religious mobilizations among South African Muslims and Hindus of Indian ancestry, Thomas Blom Hansen has remarked, "These global aspirations seek to escape the weight of local history and culture by reaching for other universals - the legacy of Arabic in the Muslim world, for instance, or India's mythological past” (Hansen 2012: 259). While these observations also largely apply to Mauritius, Indo-Mauritian Muslims and Hindus do not experience marginalization and exclusion from a new national imaginary as South Africans of Indian ancestry often do. On the contrary, religious mobilizations along the lines of globally established major religious traditions 
neatly fit the official Mauritian policy of identifying religiously grounded "ancestral cultures" as central to the postcolonial nation, a policy invented and sustained by a Hindu state bourgeoisie.

This postindependence policy of linking the cultivation of diasporic religious traditions to inclusion in the nation already provided a further impetus for religious mobilization among Mauritian Muslims. However, the origins of the current thrust toward a proliferation of signs of Muslim piety and activism can be traced to the economic boom beginning in the $198 \mathrm{os}$, and to the further intensification of global links with which it has gone along. One reason for the visible growth of orthodox and supraregional forms of Islam since the beginning of the economic boom is that more of the Muslims whose ancestors were indentured started to acquire the means for emulating the cosmopolitan lifestyles and forms of consumption of the Gujarati Muslim trader elites. The more standardized Islamic practices and affiliations of the traders began to constitute an important dimension of what most Muslims viewed as a modern, educated, and globally connected manner of living. The Gujarati trader families, who originated in South Asia-but who have, since the nineteenth century, spread around the Indian Ocean region and, in the twentieth century, to Britain and North America-are globally mobile cosmopolitans. The Islamic credentials that come with membership in particular translocal religious networks form an integral part of the networks of trade and intermarriage that provide the links between these particular Gujarati diasporas. Aspiration to higher, Western-style education also plays a large role in this process of seeking to follow the cosmopolitan lifestyles of the Gujarati traders. Interested in diversifying their businesses, elite traders have, since the Second World War, increasingly invested in the higher education of their children, many of whom have become physicians, lawyers, and other professionals. Beginning in the 1970s, Muslim descendants of indentured workers also eagerly followed suit. In short, for these Muslims, Gujarati trader elites represented a modern, cosmopolitan lifestyle in which economic power, dense transnational connections, education, and orthodox religious credentials are seamlessly connected.

The religious networks that the Gujarati traders are involved in are diverse and in competition. As already mentioned, the old rivalry between the Kutchi Memons and their chief competitors, the Sunni Surtees, also exists on the level of sectarian affiliation. The Kutchi Memons have a long-standing affiliation with the Barelwi tradition, while the Surtees have developed a deep relationship with the purist school of Deoband. In Mauritius, the latter current is, above all, manifest through the global piety movement Tabliqi Jama'at. However, since the 1970s, a third transnational network of Sunni Islam reached Mauritius, without the traditional mediation of Gujarati traders. Locally known as "Tawheed," a Salafist Islamic current began to spread when a number of Mauritian Muslims who studied in Saudi Arabia became inspired by a Wahhabi-influenced and highly purist version of Islam that-in contrast to the reformist movements of South Asia, such as the 
schools of Deoband and Bareilly_rejects the authority of the established schools of law, such as the Hanafi school, which is predominant throughout South Asia. In contrast to the Barelwi and the Deobandi traditions, which were at least initially introduced and led by Gujarati traders in Mauritius, the spread of the Tawheed current represents an attempt by some Muslims of formerly indentured family lines to connect to a large transnational Islamic movement bypassing the traditional leadership of Gujarati traders. The rise of the Tawheed is also the expression of a desire among some Mauritian Muslims to acquire cosmopolitan lifestyles and identities without having to emulate the Gujarati traders and implicitly recognize their leadership role.

It is important to understand that this trend toward religious mobilization, along with the rise of more standardized and reformist forms of transnational religion, is also embedded in a broader Mauritian politics of pluralism and nation building. According to Mauritian state policy, religious traditions with diasporic linkages to centers of religious authority in other parts of the world fulfill a key role in ensuring equitable and peaceful coexistence among Mauritians. Even more, since Mauritian state policy suggests that Mauritius is composed of "communities" that define themselves through diasporic links, adherence to one of the recognized major religious traditions that are supported as "ancestral cultures" in Mauritius has become central to local notions of citizenship. For Muslims, Islam represents the "ancestral culture" that legitimizes their place in a Mauritian nation.

\section{MEDIA IN RELIGIOUS NETWORKS}

Media infrastructures are widely considered to be among the main forces of globalization. Together with the spread of capital, they have brought about the kind of "time-space compression" (Harvey 1989) that is often regarded as the core of processes of globalization. As far as the cultural dimensions of globalization are concerned, Arjun Appadurai has pointed to the emergence of a global media imaginary that makes it possible to imagine lives elsewhere for comparison, self-evaluation, and building aspirations at a much greater scale and frequency (Appadurai 1996). It is clear that religious discourses and images have an important place in such a global imaginary; and indeed, many have credited media practices for what some have called a "return of religion" in the contemporary world. There is widespread evidence that contemporary religious mobilizations are inseparable from religious media practices, and it is clear that the presence of religion in the public spheres of many countries, as well as in transnational publics and subnational counterpublics, is formidable (Hirschkind 2006, Lutgendorf 1995, Meyer 2004, 2015, Meyer and Moors 2006, Oosterbaan 2008, Schulz 2012). There is thus a firm link between the great visibility and dynamism of religious traditions and global media infrastructures and the kind of media practices they make possible. Indeed, a global media presence has now become part of universalizing claims of several major religious traditions. ${ }^{6}$ 
The relationship between religion, media, and globalization can be cast in more specific terms. Certain religious traditions have become more visible and widespread because new media infrastructure and practices have resulted in a greater presence of religion in the public sphere. In addition to that, I suggest, there is also, from the perspective of many religious practitioners in the contemporary world, an inner relationship between the global reach and connectivity of contemporary media infrastructures and the global reach and cosmic universality that characterizes the ambitions of certain religious traditions, especially Christianity and Islam.

But there is another important link between religion, media, and global connections, one related to what scholars of religion have described as the intrinsic relationship between religion and media. This link has, at first glance, little to do with, and long predates, current processes of globalization. Religious traditions can be understood as institutionalized forms of interaction between religious practitioners and a religious otherworld, however this is conceived. Various kinds of media, with their material and technical dimensions, enable these interactions, whether in the form of images, scripture, the human voice, or nowadays, audiovisual technologies and the Internet. Furthermore, in many situations of religious media practice, there are theological foundations and motivations for the preference of certain media over others, such as the preference of scripture over images in Protestantism and mainstream reformist traditions of Islam. This intrinsic link between religion and media is a key to understanding the links between religion and the global. The phenomenological resemblance between, for example, Christian and Islamic cosmologies centered on the notion of the transcendent and the ways many people experience their position in a globalized world as attested by theorists of religion and globalization, needs to be measured against a related, second kind of resonance between the religious and the global in the field of media use. There is a parallel between mediated interactions with a religious otherworld and uses of media aimed at connecting to faraway places in a globalized world. In both cases, many project their wishes to engage with a spatially removed or transcendent other in more direct and immediate ways onto the latest media technologies. That is, at least in many Christian and Islamic contexts the drive to make "live and direct" connections with God (Engelke 2007) or other spiritual authorities resembles the desire to overcome time and space in this world through instantaneous connections in the deployment of advanced media technology.

Therefore, understanding the relationships between religion and processes of globalization is possible only when one considers the intrinsic links between religion and media. Most research on uses of contemporary media technologies in religious contexts, however, has been less concerned with the phenomenological resonances between religious and globalized media use and has instead coalesced around two main arguments. The first centers on religion in the contemporary public sphere, suggesting that the Habermasian notion of the secular public sphere is questionable, and that, moreover, the boundaries between religion, entertainment, 
and advertisement are becoming progressively blurred (Meyer and Moors 2006). Also, in this context, scholars have argued that the deployment of new media technologies in the public sphere undercuts the power of established religious authorities, such as traditional scholarship of the ulema or state institutions regulating and controlling religion, in the case of Islam (Echchaibi 2011, Eickelman 2005, Eickelman and Anderson 1999). This latter "democratization" thesis postulates a link between newer media technologies, such as the Internet, and the pluralizing of religious authority, because of the changes in access and the participation in the public sphere that they make possible. While this kind of research has put more emphasis on the interactions between people in the public sphere and the role religious matters play in them, a second, different strand of research has stressed the religiously disciplinary character of these new forms of media, in many contexts. In this work, there is a shift from focusing largely on interactions in the public sphere, toward uses of media technologies in interactions with the divine. Usage of, for example, the latest audiovisual media technologies among Muslims listening to sermons, recitations of scripture, and devotional poetry has been described as a technique of the self that brings about a state of greater piety and closeness to God (Hirschkind 2006). Here, theologies of religious mediation particular to the religious tradition at hand play a central role in guiding media practices, such as in the choice of a specific media technology over others.

As mentioned, new media technologies are not just domesticated for use in established practices of interacting with the divine; they may also be the focus of hopes for an improved and more "direct" relationship with the divine. This was the case in the introduction of printed vernacular scripture at the time of the Reformation in Europe, and in the contemporary use of sound reproduction technologies among pious Muslims in a religious tradition where the voice, especially in the recitation of scripture, has long functioned as the privileged medium of God. Here such hopes center on the intrinsic link between media and religion as traditions of interaction and communication with the divine. This link, then, becomes the focus of desires for a more "live and direct" quality of encountering the divine through the shift to a new, supposedly superior medium. Increasing numbers of religious practitioners in the contemporary world seek more direct and immediate connections with the divine or other desirable realms of value, ideally doing away with mediation as much as possible, and, ironically, they do so by deploying more and more complex technical apparatuses in pursuit of this goal. But this link between religion and media that often leads to the search for a technical solution to bring about "live and direct" interactions with a religious otherworld also has important implications for understanding the relationship between religion and globalization. The parallels between the spread of media infrastructures enabling instant forms of interaction across the globe, and the drive for instant and more immediate access to God or religious otherworlds, show the extent to which religious traditions drive the processes of globalization. That is, the fascination with 
global media infrastructures that often stand for one of the core dimensions of globalization cannot be understood in isolation from theologies of mediating the divine. At least for many Christians and Muslims, there are important religious foundations for the desire for immediate, "live and direct" interactions across large distances that characterize life in a globalized world.

In the following chapter, I show in greater detail how my Mauritian Muslim interlocutors treat technologies of sound reproduction as "vanishing mediators" (Sterne 2003). For them, sound reproduction enables seemingly more direct and immediate connections to devotional events, with their performative effects, and ultimately to God. Such media ideologies about sound reproduction also influence the maintenance of the long-distance networks of Mauritian Muslims. In this context, a sense of being a Muslim minority rather far removed from the main centers of religious authority in the Muslim world heightens concerns about orthopraxy and the authenticity of religious practices. Newer media practices designed to bring about a more direct and immediate access to remote centers of religious authority therefore simultaneously respond to two deep-seated and mutually entangled wishes. These are the desire to establish improved and more direct relationships to the transcendent, and the wish to link up more efficiently within far-flung religious networks in this world, such as those between Mauritius and South Asia. Safeguarding the appropriateness and authenticity of na't poetry performances through mediatic connection to centers of Islamic authority in India and Pakistan is one particular example of a broader role that contemporary audiovisual media play in intensifying the global links in the Muslim world. Such religious media practices among Mauritian Muslims show that the search for more immediate relationships to the divine and more direct connections within transnational religious networks in this world are closely intertwined. 